\title{
Urban planning and landscape framework of church architecture of the Tsarskoye Selo district of St. Petersburg Province
}

\author{
Nadezhda Akulova ${ }^{1, *}$, and Sergey Sementsov ${ }^{1}$ \\ ${ }^{1}$ Saint Petersburg State University of Architecture and Civil Engineering, Vtoraya Krasnoarmeiskaya, \\ 4, 190005, St. Petersburg, Russian Federation
}

\begin{abstract}
The historical Tsarskoye Selo district of St. Petersburg province is one of the interesting phenomena of urban planning and cultural development of Russia. The article considers only one of the lines of the formation of the county - the development of multi-confessional temple-building on its territory as part of the improvement of a single territorial-landscape system over six chronological stages: up to 1703 ; $1703-1779 ; 1780-1800 ; 1801-1836 ; 1837-1900 ; 1901-1917$ As you know, temple architecture has not only powerful sacred-semantic components, but also reflects the most important architectural-figurative and urbanterritorial aspects. Until 1917, it was the temples and the accompanying buildings and structures of various faiths that accumulated many features of territorial and cultural centers. Thus, forming a special multi-temple framework throughout the county, wider - in the province. The identification of this historical framework and the definition of its features within the framework of a single county was the topic of this article.
\end{abstract}

\section{Introduction}

There is no research in modern scientific literature. In which at the same time temple constructions in a certain large territory would be considered both a confessional phenomenon, and from the point of view of city-forming processes. Known works devoted to separate consideration of these problems.

\section{Methods}

To identify the materials published in this article, stage-by-stage complex historicalarchival and historical-urban planning, cartographic, bibliographic studies were carried out with the implementation of comparative analysis techniques.

\footnotetext{
* Corresponding author: naroma@list.ru
} 


\section{Results}

The historical Tsarskoye Selo district is the territory of constant attention of researchers. Indeed, such unique world-class palace and park ensembles are concentrated on its territory - the State Museum-Reserves (GMZ) Tsarskoye Selo (with the accompanying historical double city of the Palace Department: Palace Sloboda - Sofia), the GMZ Pavlovsk (with the historical city of the Palace departments of Pavlovsky), the Gatchina State Museum of Arts (with the historical court city of Gatchina), as well as Krasnoye Selo - the city of the Imperial Headquarters and the summer camps of the Russian Guard, in the vicinity of which annual maneuvers were held. But this list almost exhausts public and scientific interest. Out of the general field of vision, and almost unknown, dozens of unique estates of the Higher nobility, as well as the rings of noble estates surrounding them. Numerous barracks towns of the guards and army regiments - permanent and summer - remain without attention. Many residential and industrial complexes and related settlements turned out to be even more forgotten. Only in recent decades have they begun to pay certain, but clearly insufficient attention to the phenomenon of summer cottage construction and summer cottage settlements in the mid-late 19th century in this zone.

Under these conditions, without rejecting or denying the inclusiveness of attention to the magnificent summer imperial residences, any attempt at a professional look at other objects and other functions in the suburban metropolitan district seems important and informative.

Tsarskoye Selo County is unusual not only in that it included the largest palace and park ensembles, but also in that it was an almost experimental example and model for all of Russia. It was on his example that Catherine II, Alexander I and Nicholas I proclaimed the idea of creating exemplary county-level cities and exemplary counties. According to D.O. Shvidkovsky it was the project of the "ideal city" of Sofia (the suburbs of Tsarskoye Selo since 1780) and its implementation became exemplary for Russian urban planning of the second half of the XVIII century. [1]. This "exemplary" was gradually expanded to the entire county, in accordance with the requirements from the 1830s - 1840s. Nicholas I, so that the entire county is also an exemplary county [2].

The inextricable consideration of the development lines in the entire county (as a complex spatial-landscape unit) deserves a special approach.

One of the clear unifying lines of development of the entire county as a whole was temple construction. Temples are traditionally considered as powerful historically formed or modern semantic and symbolic objects, less often temples are studied as urban objects. But, a one-time study of large territorial entities (such as a region, province-region, countydistrict), allow us to note other, special characteristics that are undeservedly falling out of the field of view of researchers.

The historical Tsarskoye Selo district (which existed within the borders that had been established from the beginning of the 19th century up to the 1920s) is partially preserved in the territories of the modern Pushkin district of St. Petersburg. Its foundation since the XIV century. there were graveyards of the Novgorod Vodskaya Pyatina: Vvedensky Duderovsky, Nikolsky Izhersky, Bogoroditsky Diaghilensky. From 1580-1582 these territories were occupied by Swedish troops, and as part of the Swedish Ingermanlandia (practically preserving the Old Russian administrative-territorial division - i.e. including Duders Pogost, Ingris Pogost, Deglinskoi Pogost,) they existed until 1703-1704, when the offensive of the Russian army returned land to Russia.

A study of archival sources and published data made it possible to identify about 100 temples in the territory of Tsarskoye Selo Uyezd that were created before 1917 and have different features. 


\section{Discussion}

And this was historically predetermined not only by the fact that these territories experienced several different periods of their existence. Starting from the medieval periods (which we conventionally combined into one stage of the pre-Petersburg temple architecture): - Novgorod (up to 1478) and Moscow periods (1478-1580) distribution of Orthodox churches - known to us from chronicles and scribes, then - the Swedish period (1580-1700s), with the creation of new Swedish Protestant churches and the parallel reconsecration of ancient Orthodox churches. And from the 1710s., Throughout the XVIII early XX centuries. (within the next five stages of development), in the suburban Tsarskoye Selo district, not only the mass construction of Orthodox churches was conducted, but also non-Orthodox churches, to ensure the religious comfort of the residence of many representatives of different European countries, called up for service in Russia and united in non-Orthodox religious and ethnic communities - British, Germans, French, Swedes, Dutch, Danes, Spaniards, etc. Of the currently known on the territory of Tsarskoye Selo Uyezd, almost 100 historical churches of various faiths, of course, more than $3 / 4$ are Orthodox. Naturally, such a different denomination of churches necessarily predetermines different volumetric, spatial, compositional, silhouette, and stylistic characteristics.

In addition to the confessional differences, the temple architecture of the county fully reflected the different urban planning and architectural patterns of the formation of natural and man-made landscapes, highlighting the significant planning and architectural differences in which these temples existed:

1. Temples located in different types of man-made urban-landscape ensembles and settlements:

a) temples (detached and house) located in the imperial palace and park suburban residences (Pavlovsk, Tsarskoye Selo, Gatchina);

b) temples (detached and house), located in the estates of the Highest nobility;

c) temples located in the structures of multifunctional settlements (or between settlements), including: monastery courtyards; temples (detached and house) at the facilities of military departments (for example - in the area of the Red Village), with numerous regimental, battalion and other military settlements; temples (detached and house) in residential towns, settlements, settlements, as well as between residential settlements (including parish churches and chapels, temples in administrative buildings, educational institutions, charity, charity and medicine); temples (separate and house) at industrial enterprises (manufactories, factories) and / or in industrial settlements;

d) prison churches (detached and brownies);

e) churches in cemeteries.

2. Temples (detached) located on ancient and modern communications: on land highways and roads (on state roads, highways, ancient and new roads), along the banks of waterways (on the banks of rivers and lakes, on islands, in water courses fairways), along the highways.

3. Temples located between villages, becoming the connecting landscapecompositional nodes between these villages and spaces.

The buildings and constructions of all these groups had and still have (if they have survived to our time) not only confessional differences, but they have also absorbed obvious urban development features that respond to the specific laws of the surrounding man-made and natural spatial landscapes.

The temple building of Tsarskoye Selo County fully inherited the polyrhythmics, the staged development of the county itself, and therefore, for the different stages of the formation of the county (and the creation of temples), the features of their (temples) spatial 
distribution relative to the surrounding buildings and landscapes, the dynamics of construction and reconstructions.

The chronological dynamics of the formation of temples of various faiths within the boundaries of the county are clearly visible when taking into account the data of each stage.

The first stage: DOPETERBURG (until the 1700s). A study of archival data from the Scribes of the Novgorod, Moscow, and Swedish periods, as well as Swedish cartography in the territory of the future Tsarskoye Selo district, revealed not only the location of hundreds of villages (noble estates, manors, villages, villages, hamlets), a single network of roads for various purposes, but also temples - Orthodox and Swedish Protestant. So, even the names of the graveyards of Novgorod (up to 1478), Moscow (in 1478-1580) periods show that Orthodox churches were located on the territories of graveyard centers: the Entry Into the Church of the Most Holy Theotokos (in Vvedensky Duderovsky graveyard), Nicholas the Wonderworker ( in St. Nicholas Izhersky churchyard), In the name of the Most Holy Theotokos (in the Mother of God Diaghilen churchyard). And in the Swedish period of life, among the many nameless churches shown on the map of Ingermanland in the territories of the future Tsarskoye Selo Uyezd are marked: in the upper river. Slavs - Past [orat], SlavankaK [ÿrkia] - Protestant pastor; on the bend of the river. Izhora, in the place of the future estate of A.D. Menshikov - IngrisK [ÿrkia] (ie - Izhora Church), south - Koprina Kÿrkia (Koporskaya Church); west of the highway to Narva - RÿskK [ÿrkia] (Russian Church), again RÿskK [ÿrkia] (again the Russian Church), etc. [3].

The second stage: 1703-1779 years. At this stage of the initial formation of St. Petersburg and its suburbs, the construction of churches of various faiths, as well as the repair and re-consecration of the Orthodox and non-Orthodox churches that existed before the foundation, was noted. Among the most famous and often mentioned, one can now note some of the largest churches in these cities, including at imperial residences and parishes: the church In the name of the Most Holy Life-Giving Trinity in Krasnoye Selo (1733-1735, architect I.Ya. Blank), two churches in Tsarskoye Selo: In the name of the Icon of the Mother of God "The Sign" (1734-1747 ., architect I.Ya. Blank, architect M.G. Zemtsov) [4], church In the Name of the Resurrection of Christ, in the Grand Catherine Palace (17461756, architect F.-B. Rastrelli) [5 ].

The third stage: 1780-1800. The last two decades of the XVIII century. marked by intensive work in the field of temple construction, not only in imperial residences, but throughout the county.

Gatchina. Since 1766, the suburban residence of Count G.G. Orlova (favorite of Catherine II). There was built the Court House Church of the Gatchina Palace - In the Name of the Holy Life-Giving Trinity (1780-1782) [6]. And in 1799, Emperor Paul I planned to build a man's Kharlampiev monastery in the Sylvia park with the church in the name of St. Harlampiy for the eternal storage and veneration of Christian shrines transferred from the Order of Malta, including - The hand of St. John the Baptist. But the idea of Paul I did not have time to implement.

Pavlovsk. In 1780, the court residence of the Heir to the Throne Pavel Petrovich Pavlovsk was founded. At the same time, the creation of not only the Pavlovsk Palace (architect Ch. Cameron), with extensive parks, but also the city of the Court Department with many churches began. Among them, one can mention the Church In the Name of St. Mary Magdalene (1781-1784) [7]. Fifteen years later, a house Church was built in the system of the Pavlovsk Palace in the name of the Holy Apostles Peter and Paul (1796-1799) [8]. And in 1799, the Roman Catholic chapel of St. John the Baptist was erected in the miniature fortress "Bip".

Tsarskoye Selo. From January 1779 (1780?) To the south of the Tsarskoye Selo imperial palace and park ensemble, the creation of the district city of Sofia, with the central city district and, at the same time, the memorial church in honor of the victories of the 
Russian troops in the Russian-Turkish Wars, the church In the name of Ascension of the Lord (Hagia Sophia). Sofia Church was built in 1782-1788. (architect C. Cameron, architect I.E. Starov) [9]. But since the beginning of the XIX century. the idea to create a model city passed to Palace Sloboda (located northwest of the imperial residence), and Sofia was transferred to the housing of the guard regiments [10].

Among the churches of this large spatial and highly responsible node: the imperial palace and park residence - the district city of Sofia - Palace Sloboda of the Court Department, several more churches were built over two decades, including the Church of the Annunciation (1785), the church Kazan Icon of the Mother of God (1785-1790, at the city cemetery), a church at the entrance north of Tsarskoye Selo - at Pulkovo: Church In the Name of the Smolensk Icon of the Mother of God (1780-1784, architect J. Quarenghi); in the villages of Nikolskoye, Slavyanka (Slovyanka), Fedorovskoye, Alexandrovka.

The fourth stage: 1801-1836. As part of the administrative reform of 1796, the territory of the abolished Rozhestvensky Uyezd (with its center in the district town of Rozhestveno) became part of Tsarskoye Selo Uyezd, significantly expanding it to the south. This led to a new wave of construction of Orthodox and heterodox (mainly among them the Evangelical Lutheran and Roman Catholic) churches. It is worth noting that among the Upper World it was fashionable to worship the ideas of the non-Orthodox Church in those days, therefore, in some palaces and in some estates, the construction of non-religious houses and separate churches was carried out (but they did not take such a significant place in the general list of erected churches).

The construction of churches during this period is carried out mainly in the zones of Gatchina and Tsarskoye Selo, but temples appear in more remote territories: in estates of the Highest nobility, in ordinary noble estates, in villages, villages and industrial settlements. At the same time, after 1819 the heyday of Krasnoye Selo began - with the organization of summer military camps here of regiments of the Guards Corps and the accompanying Imperial Headquarters. In general, for this stage, an increase in the volume and intensity of temple building in different landscape conditions of the county can be noted.

For these decades, several large territorial locations of temple construction can be noted.

Organization of a new main entrance to St. Petersburg. In 1803-1804 The main entrance to St. Petersburg was officially changed. Throughout the XVIII century. Entrance to the city was made from the southern coast of the Gulf of Finland, along the Peterhof Highway, where Narva Square is now located, where the Narva Triumphal Gates were located since 1814. But, since 1804, they began to gradually form a new main entrance to the city along the Tsarskoye Selo road (Bud. Zabalkansky - International Ave. - Moscow Ave.). Therefore, in the 1800s - 1810s. along this nascent entrance, work began on accelerated and improved landscaping and better development. Among the major landscaping works was the putting in order of the Chesmensky town (Chesmensky invalid home) with the construction of the church There in the Name of the Nativity of Christ (1812).

Gatchina. During these years, the following buildings were erected in Gatchina: Church in the Name of St. Peter the Apostle (1802), Church in the Name of St. Paul the Apostle (1820-1823, attached to the City Hospital, architect AE Staubert) [11], Church In the name of the Holy Good. Prince Alexander Nevsky (1824-1826, at the Orphan Institute) [12; 13], the church of St. Nicholas the Wonderworker (1828), the gate church In the name of St. Paul the Apostle (1830-1831, Ingerburg) [14].

Tsarskoye Selo. Several churches were also built in the city, primarily in hospitals and charity houses for wounded and sick soldiers. For example, the church In the Name of the Icon of the Mother of God of All Sorrowful Joy (1809-1817, at the Tsarskoye Selo hospital and almshouse), the church in the Name of the Transfiguration of the Lord (1818), the house church at the Alexander Young Cadet Corps (1822-1826 .). And among the 
heterodox churches, we can mention the Roman Catholic Church of St. John the Baptist (1811).

Churches were also built in the villages of Duderhof and Pyataya Gora, in the villages of Orlino, Staro-Panovo and other settlements. In the village of Druzhnoselje, on the estate of Field Marshal Prince Wittgenstein (donated to him by St. Petersburg merchants as "the savior of St. Petersburg from Napoleon's troops"), the Catholic Church of St. Martyr Stephenida was erected.

Fifth stage: 1837-1900. In the decades of this period, major design and urban development work was carried out: settlement projects (modern - master plans) of Tsarskoye Selo, Sofia, Gatchina, Pavlovsk, and Krasnoye Selo were developed and approved, taking into account, among other things, the location of temples, which were to become composition centers these cities. As, for example: in Gatchina - the cathedral In the name of St. Paul the Apostle (1846-1852, architect RI Kuzmin); in Tsarskoye Selo - the cathedral In the name of St. Catherine the Great Martyr (1835-1840, architect K.A. Ton). The geography of temple architecture in the county at this stage has also been significantly expanded. The new large areas of mass construction of various churches were the summer cottages created throughout the county (as well as throughout the province), which attracted tens, even hundreds of thousands of summer residents, in the spring and summer. Of course, wooden churches were built without fail in such towns.

Gatchina. Back in the 1830s. The Large Court Stables, placed by order of Paul I south of the Gatchina Palace, were rebuilt to accommodate the lh.v. The cuirassier of Her Imperial Majesty regiment. Then, in these barracks, the Church In the Name of St. Nicholas the Wonderworker (1858-1861, architect Stepanov) was organized. And in Ingerburg (Gatchina) during the reconstruction of the barracks 1. Guards The garrison battalion for the quarters of the 23rd Artillery Brigade built a church in the name of St. Sergius of Radonezh (1878-1893) [15].

Krasnoye Selo. In Krasnoye Selo, in its environs - in Duderhof, Annino, in other villages, guard regiments were stationed annually for the summer season, in Krasnoye Selo they built the Imperial Headquarters with the General Headquarters (or the headquarters of the Guards Corps). Wooden churches were built in the headquarters and regiments and / or regimental camp churches were deployed. Among these churches can be noted: a wooden church In the name of St. Blessed Princess Olga (1879-1885, in Duderhof), a wooden church in the name of St. Blessed Prince Alexander Nevsky (1890, in Krasnoye Selo), a wooden church In the Name St. Blessed Prince Alexander Nevsky (1890, at the military field hospital in Krasnoye Selo, military engineer V.A. (MA?) Kolyankovsky), wooden church In the Name of All Saints (1894, in Summer camp of the LHV of the Cavalier Guard regiment, in the village of Annino, near Krasnoye Selo).

Pavlovsk. During this period, the construction of churches In the name of St. Nicholas the Wonderworker (1840) and In the name of St. Joachim and Anna.

Tsarskoye Selo. During this period, one can especially note the device of the brownie, on the 2nd floor of the church building In the Name of the Nativity of the Blessed Virgin Mary, famous in the history of Russian culture of the late XIX - early XX centuries. Tsarskoye Selo Nicholas Grammar School (1870-1872).

At the same time, the construction of churches was carried out in many villages of the county - in Yam-Izhora, Lisino, Mane, and Voskresensky.

This unified temple-building process is characterized by the history of expansion of the St. Petersburg city Vokresensky Novodevichy Convent (modern address - Moskovsky pr., 100). In 1884, the monastery arranged a monastery compound outside the borders of St. Petersburg in the "dense pine forest" near the village. Vohonovo, on the territory of Tsarskoye Selo County. Here a wooden church was quickly cut down In the name of St. Mary Magdalene (1884). Soon the monastery received the status of a convent. Then at s. 
The Fifth Mountain on a site donated to the newly formed monastery near the Maryino estate built wooden residential buildings and churches: a chapel church in the name of the Icon of the Mother of God "Satisfy My Sorrows" (1895), a church in the name of the Transfiguration of the Lord (1906). Even in the process of these construction works, the newly created courtyard also received the status of the Pyatogorsky Bogoroditsky Convent (Pyatogorsky - by the name of the village Pyataya Gora). Both monasteries - Vohonovsky and Pyatogorsky continued to remain under the jurisdiction of the St. Petersburg Resurrection Novodevichy Convent [16].

Then, the Pyatogorsky monastery itself expanded its influence by placing the "Kikinsky Compound" (since 1896) in Gatchina, with two churches In the Name of the Intercession of the Most Holy Theotokos: first a temporary house, then a separate, large, five-domed church (in 1916, architect Kharlamov M.L., architect Baryshnikov A.A.). And at the railway station. "Kikino" built a brick church In the name of St. Great Martyr Panteleimon the Healer at the railway station Kikerino (1906) [17].

Sixth stage. 1901-1917 years. Since the beginning of the XX century. the trends of intensification of the development of the territories of Tsarskoye Selo Uyezd as a whole and expansion of the scale of temple construction intensified even more.

By the early 1900s The county was undergoing significant changes. Along with the development of traditional spatially functional units, primarily the imperial palace and park ensembles of Gatchina, Pavlovsk, Tsarskoye Selo (with the placement of accompanying guard regiments and residential towns of the Imperial Court department), with the rapidly developing Red Selo as the summer residence of the Court and the Guards, a large industrial belt was formed on the territory of the county to this chronological line, originating from Ust-Izhora with the famous Izhora Admiralty Plants and Kolpi skim Posad (not city!), and extending along the rivers Izhora and Slavyanka. At this time, along the "departing" from St. Petersburg land and railways roads began to rapidly develop large and largest suburban centers (in the tens of thousands of suburban areas), as well as nodes and even belts of a completely new urban development phenomenon - the belt of "cities (towns) - gardens" [18; 19; 20].

Such new largest formations - cottages, summer cottages and "city gardens" in the county can be safely attributed to the very intensively expanding Vyritsa, Vyru, Druzhnoselye, Kezev, Malaya and Bolshaya Zagvozdki, Petropavlovsk, Rozhdestveno, Sergievka, Siverskaya, Sivoritsy, Suydu, Thais. By 1913-1914 they became comfortable settlement-towns for year-round living, with their own transport (including railway, horsedrawn, omnibus), with electricity, with telephone and telegraph communications with St. Petersburg, with the construction of schools, shops, clubs, sports facilities, of course temples. All these cities, towns, villages, groups of villages were "strung" on a system of roads with constant transport links with the capital. All this as a whole led to a considerable extent to the territorial expansion and qualitative development of the St. Petersburg metropolitan area and, as its most important component, the temple system.

In general, in these years it is already difficult to distinguish temple architecture in cities, in major centers, in military towns, or in summer cottages. All of them are mutually complementary.

Alexandrovka. A church was built In the name of the Kazan Icon of the Mother of God (1907-1910).

Vyritsa. In the largest zone of formation of a huge "garden city", for tens of thousands of residents and hundreds of thousands of summer residents in the early 1900s. already had its own railway with several stations, 4 churches were built, among them: a wooden hipped Church of the Holy Apostles Peter and Paul (1906-1908, citizen engineer N.I. Kotovich); wooden church In the name of the Kazan Icon of the Mother of God (1914) [21]. 
Gatchina. At the beginning of the XX century. built: the Russian-Estonian churchschool of the Assumption of the Blessed Virgin Mary (1907-1909, architect V.M. Lopatin), a house church in the name of the Most Holy Life-Giving Trinity (1907-1908, (under the Gatchina Real School of Emperor Alexander III - 4th high school).

Krasny Bor. Church-school of St. Nicholas the Wonderworker (1902).

Pavlovsk. In Tyarlevo, in the northern suburbs of Pavlovsk, in memory of the 300th anniversary of the Romanovs, a white stone carved church was built in the Name of the Transfiguration of the Lord (1912-1914, citizen engineer A.A. Zakharov, citizen engineer N.L. Rklitsky )

Thais. The Church of St. Alexis, Metropolitan of Moscow (1914, architect I.V. Eskuzovich) was built.

Tsarskoye Selo. Among the many works in Tsarskoye Selo, of course, the regimental temple of the Consolidated Infantry Regiment stands out - the Sovereign Cathedral In the name of the Theodore Icon of the Mother of God ("Theodorovsky Sovereign Cathedral", 1909-1914, architect V.A. Pokrovsky), built in "Russian style" of the XV-XVI centuries. $[22 ; 23]$. But, of course, other churches were also created, for example - in those same years a house church was built in Tsarskoye Selo in the mansion of O.V. von Hohenfelsen (Paley): Church In the Name of the Annunciation of the Blessed Virgin Mary (1911-1914) [24].

\section{Conclusions}

In conditions of mass temple-building on the territory of the historical Tsarskoye Selo district, several features can be noted.

1. Consistently, over several stages, formed by the beginning of the XX century. An extensive spatial-landscape and symbolic-semantic network of temples throughout the entire Tsarskoye Selo district can be defined as a unique single temple framework dense in terms of placement within the entire county. Moreover, a clear understanding of the parallelism and qualitative unity of development of all counties of the capital province allows us to talk about a single temple framework for the entire St. Petersburg province, in which the temple architecture of Tsarskoye Selo district is a significant fragment.

2. On the territory of the county, both brick churches (in the cities of the county) and wooden churches (in the settlements of seasonal visits and in summer cottages) were simultaneously erected. Very often, especially in areas of summer cottage construction, in areas of the creation of "garden cities", industrial settlements, monastery courtyards, etc. wooden churches were massively erected, while "honing" the architectural features of wooden urban architecture.

3. If we reach the level of the province as a whole, then the system of placement and development of churches can be considered as one of the elements (layers) of the formation of the St. Petersburg metropolitan area. The temple framework of Tsarskoye Selo Uyezd and St. Petersburg Province is one of the significant elements in the formation of the St. Petersburg agglomeration.

\section{References}

1. D.O. Shvidkovsky, The ideal city of Russian classicism. Denis Didro and the culture of his era (pp. 162-214, Moscow, 1986)

2. PSZRI, 2nd collection, Part 1, 22, No. 21515, 699-700, St. Petersburg (1847)

3. Map from the Royal National Library, Stockholm, Sweden (1704) 
4. V.V. Vasiliev, Tsarskoye Selo "Sign" (Ill., p. 32, ANO "St. Petersburg Center for Humanitarian Programs", St. Petersburg, 2010)

5. I. Yakovkin, History of Tsarskago Village. Part 1 (pp. 47-48, St. Petersburg, 1829)

6. V.K. Makarov, A.N. Petrov, Gatchina (Ill., p. 304, 2nd ed., Rev. and add., Publ. Sergey Khodov, St. Petersburg, 2005)

7. Materials about the cities of the Court Department: City Pavlovsk and Manor Strelno (p. 60, Type. Department of Udelov, St. Petersburg, 1882)

8. V. Kurbatov, Pavlovsk. Artistic and historical essay and guide (Ill., p. 18, 2nd ed., Publ. Communities of St. Eugenius of the Red Cross, St. Petersburg)

9. N. Belekhov, A. Petrov, I. Starov, Materials for the study of creativity (Ill., p. 178, Academy of Architecture of the USSR, Moscow, 1950)

10. Hundred service of L.-G. Hussars of His Majesty's Regiment. Historical essay (p.41, Type. Partnership "Public benefit", St. Petersburg, 1875)

11. V.V. Klavina, Temples of the St. Petersburg Diocese (Ill., p. 200, St. Petersburg, 2004)

12. Historical and statistical information about the St. Petersburg diocese, 10, 138-139, St. Petersburg (1885)

13. L.F. Kulyakhtina, East. Gatchina through the centuries magazine, 1-5

14. O.V. Petrova, The city of Gatchina in the projects of architects of the XVIII - XIX centuries. From the collection of the State Museum-Reserve "Gatchina" (pp. 25-28, St. Petersburg, 2005)

15. S.V. Vokhonovsky, Historical and literary journal, 54, 900-906, St. Petersburg (1893)

16. E.A. Popovitsky, P.P. Soikin, Orthodox Russian Convent. A full illustrated description of all Orthodox Russian monasteries in the Russian Empire and Mount Athos (p. 193, Publishing House P.P. Soykina, St. Petersburg, 1909)

17. N.A. Akulova, Bulletin of the Belgorod State Technological University, 4, No. 8, 9198 (2019)

18. S.V. Sementsov, Bulletin of Civil Engineers, No. 5 (70), 26-49, SPbGASU (2018)

19. S.V. Sementsov, N.A. Akulova, Urban construction and Architecture, 9, No. 2, 118 127, Samara State Technical University (2019)

20. A. Baranovsky, Vyritsa under the tsar. Country Petersburg (p. 308, 2nd ed., Island, St. Petersburg, 2007)

21. Yearbook of the Society of Architects-Artists, issue 5, pp. 109-112 (1910)

22. Yearbook of the Society of Architects-Artists, issue 7, 98-102 (1912)

23. I.G. Tokareva, Leningrad panorama, No. 8, 33-35 (1987) 